\title{
МОВОЗНАВСТВО
}

УДК 81 '22

DOI: http://dx.doi.org/10.30970/fpl.2018.131.2134

\section{THE POTENTIAL OF INTERPRETANT FOR DEFINING LEVELS AND DIMENSIONS OF SEMIOSIS}

\author{
Nadiia Andreichuk \\ Ivan Franko National University of Lviv, \\ 1, Universytetska St., Lviv, Ukraine, 79000, \\ nadiyaan@gmail.com
}

This paper attempts to explore some potential contributions of Ch. W. Morris' ideas on semiosis to the development of semiotic theory. Proceeding from the conviction that semiotic study, following Peirce, actually consists in analyzing the sign's action, i. e. semiosis, the author exposes the views of Ch. Morris on the latter and tries to provide evidence that some of his ideas concerning the dimensions of semiosis can be viewed with reservation. It is claimed that the starting point for determining such dimensions is the interpretant - the integral element of sign and the outset of semiotic inference. The triadic nature of interpretant is substantiated and three types of interpretants - primary, notional and cultural - are singled out. It is brought to light that each type of the interpretant "works" on a different level of semiosis: perceptive, informational and evaluative, correspondingly. The correlation of interpretants and levels of semiosis is extended to establishing relations between interpretants and objects. The analysis of these relations on different levels leads to the substantiation of three dimensions of semiosis: code, informational, and cultural.

Keywords: Ch. Pierce, Ch. Morris, sign, semiosis, interpretant, object, levels of semiosis, dimensions of semiosis.

\section{Semiosis explains itself by itself: this continual circularity is the normal condition of signification (U. Eco)}

Introduction. Modern semiotics as a meta-science has influenced, through its methods and applications, almost every field in the humanities and sciences. Its current understanding was shaped in the works of three scholars: Ferdinand de Saussure (1857-1913), Charles Sanders Peirce (1839-1914) and Charles William Morris (1901-1979). In this paper we mostly focus on Morris' semiotics and his ideas concerning dimensions of semiosis.

The semiotic study, following Peirce, actually consists in analyzing the sign's action, i.e. what Peirce calls semiosis or semeiosy.' He uses both forms of the term in his article "Pragmatism" written in 1907. Here Pierce writes about "semiosis" or "semeiosy" as action of a sign" and provides the following explanation:

1 Here and further in this text highlighting in bold type is done by the author of this article.

(C) Andreichuk Nadiia, 2018 
"It is important to understand what I mean by semiosis. All dynamical action, or action of brute force, physical or psychical, either takes place between two subjects [whether they react equally upon each other, or one is agent and the other patient, entirely or partially] or at any rate is a resultant of such actions between pairs. But by "semiosis" I mean, on the contrary, an action, or influence, which is, or involves, a cooperation of three subjects, such as a sign, its object, and its interpretant, this tri-relative influence not being in any way resolvable into actions between pairs" [12].

In the same article Pierce introduces the term semeiosy to speak about the "action of sign" having a "triadic character". Defining semiosis as the action of the three relata, Pierce emphasizes that signs acquire more meaning through their own activity and that dynamicity of semiosis is a crucial feature of this semiotic activity. The word "semiosis" was borrowed by Pierce from the Epicurean philosopher Philodemus'; according to Pierce, it is an experience which everyone has at every moment of life. To explain this experience, we need a special theory which he calls semiotics, adding that it is another name for logic:

"Logic, in its general sense, is, as I believe I have shown, only another name for

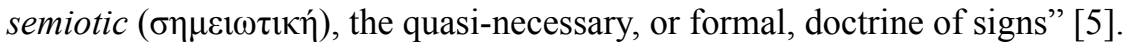

A few years later Pierce specified that:

"...the one sole way to success in logic is to regard it as a science of signs; and I defined it in 1867 as the theory of the relation of symbols to their objects. Further experience has convinced me that the best plan is to consider logic as embracing more than that, and the general theory of signs of all kinds, not merely in their relation to their objects but in every way. This way of looking upon logic is the one salvation for the science" [5].

No introduction to the Peircean science of signs, however brief, will fail to mention that the sign is a triadic relation and that it can be defined as something that stands for something else (its object) for something third (its interpretant), or alternatively as something that mediates between its object and its interpretant. Peirce adopted the term "object" from the 13th century scholastic terminology, where "objectum" meant "a creation of the mind in its reaction with a more or less real something [...] upon which cognition is directed" (cit. from [8, p. 29-30]).

The most obvious mark of a sign is its structure, which distinguishes it from monadic and dyadic relations. Pierce differentiates between sign-action (semiosis) and sign-representamen which is the point of departure of semiotic inference. This led him to use "sign" when speaking of the sign in action and "representamen" when analyzing the constituent elements of semiosis. These constituents are the representamen, the interpretant and the object, which he calls the "Immediate Object" within semiosis in order to discriminate the object outside semiosis which he calls the "Dynamical Object":

1 Philodemus of Gadara (ca. 110 - ca. 30 BC) was an Epicurean philosopher and epigrammatist who studied in the Epicurean school at Athens led by Zeno of Sidon. Philodemus was under the influence of Epicurus who was, perhaps, the originator of the Hellenistic debates over the nature and existence of a 'criterion of truth', which allows us to separate true from doubtful or false beliefs. This debate, conducted by both philosophers and medical writers, also concerned methods of proof and sign-inference to extend knowledge beyond our immediate perceptions [2]. For more details on Epicurean sign-inference (sêmeiôseôn) in Philodemus see [1, p. 194-241]. 
“...every sign has two objects. It has that object which it represents itself to have, its Immediate Object, which has no other being than that of being represented to be, a mere Representative Being, or as the Kantian logicians used to say a merely Objective Being; and on the other hand there is the Real Object which has really determined the sign [,] which I usually call the Dynamical Object, and which alone strictly conforms to the definition of the Object" [4].

In letters to Lady Welby, he uses a different term explaining the difference between two objects:

"As to the Object of a Sign, it is to be observed that the Sign not only really is determined by its Object, - that is, for example, the name Charlemagne is in correspondence with the historic Emperor who lived in the IXth century, or the name Othello is fitted to that Moorish general whom Shakespeare imagined, or the name "the Ghost in Hamlet" is fitted to that ghost of an ancient King of Denmark that Shakespeare imagined that Prince Hamlet either imagined or really saw, - but in addition, the Sign may be said to pose as a representative of its Object, that is, suggests an Idea of the Object which is distinguishable from the Object in its own Being. The former I term the Dynamoid Object (for I want the word "genuine" to express something different); the latter the Immediate Object (a well-established term of logic.) Each of these may have either of the three Modalities of Being, the former in itself, the latter in representation" (1908, Letters to Lady Welby) [4].

Thus, Peircean logic assumes that all knowledge is obtained from triadic sign action of pointing to an external world - however, not to real objects but to semiotic objects as they are represented by signs which point to our phenomenal world. The followers of Pierce's ideas believe that "semiotic logic leads us to a new methodology, an integrated methodology for inquiry involving the unification of science and phenomenology" [10].

Theoretical Background. It was the great ambassador, Charles Morris, who foresaw more of the universal possibility and potential of semiosis for the science of semiotics. In his "Foundations of the Theory of Signs" $(1938)^{1}$ he discusses what he calls "dimensions of semiosis" (syntactical, semantical and pragmatical) and states that semiotics as the study of semiosis can be divided into three interrelated disciplines: (1) syntactics (studies the methods by which signs may be combined to form compound signs); (2) semantics (the study of the signification of signs) and (3) pragmatics (the study of the origins, uses and effects of signs). The basic relation of the latter sciences to semiotic is variously indicated by the terms "component discipline" [6, p. 52], "discipline (of)" [6, p. 52], "component" $[6$, p. 53], "subscience" [6, p. 53], "subordinate science" [6, p. 8], "subordinate branch" $[6$, p. 8], and "branch" [6, p. 13]. For my further presentation I choose "(is a) subdiscipline (of)" as a representative term. These subdisciplines can nowadays be found in any textbook on linguistics.

1 A collection of Morris's most important writings on semiotics and the philosophy of language, entitled "Writings on the General Theory of Signs," was published in 1971 [7]. Part one consists of "Foundations of the Theory of Signs" (1938), Part two consists of "Sign, Language and Behavior" (1946) and Part three ("Five Semiotical Studies") consists of the first chapter of "Signification and Significance" (1964) and four other studies: "Esthetics and the theory of Signs", "Signs about Signs about Signs", "Mysticism and its Language and Man Cosmos Symbols". 
Morris defines semiosis as "the process in which something functions as a sign":

"The process in which something functions as a sign may be called semiosis. This process in a tradition which goes back to Greeks, has commonly been regarded as involving three (or four) factors: that which acts as a sign, that which the sign refers to, and that effect on some interpreter in virtue of which the thing in question is a sign to that interpreter. These three components in semiosis may be called, respectively, the sign vehicle, the designatum and the interpretant; the interpreter may be included as a fourth factor" [6, p. 3].

For Morris the sign vehicle becomes a sign because it is interpreted as a sign of something by its interpreter. He emphasizes that four components involve one another and are ways of referring to the process of semiosis, and something can become a sign "only because it is interpreted as a sign of something by some interpreter" [6, p. 4]. The properties of being a sign, a designatum, an interpreter or an interpretant are relational properties which things take on by participating in a functional process of semiosis.

To describe the process of semiosis, Morris uses a rather vague term mediated-takingaccount-of [6, p. 4]. An interpreter mediately takes account of something, and interpretant which is evoked by something functioning as a sign is explained as taking-account-ofsomething. As the notion of interpretant is the key one for this research, it should be mentioned that Morris treats this notion differently in different parts of his work: a) "the effect on some interpreter in virtue of which the thing in question is a sign to that interpreter" [6, p. 3]; b) "a-taking-account-of-something in so far as it is evoked by something functioning as a sign" [6, p. 4]; c) "the habit in virtue of which sign vehicle can be said to designate certain kinds of objects or situations; as the method of determining the set of objects the sign in question designates, it is not itself a member of that set" [6, p. 34]; d) "part of the conduct of the individual" [6, p. 39]. One cannot but agree that the interpretation of the phrase "taking account of" is behavioristic ${ }^{1}$ and not sufficient for a complete study of semiosis.

Actually, in developing the ideas concerning the triadic relations of semiosis, Morris indicates three components: sign vehicle, designatum and interpreter, completely omitting the interpretant. Suggesting the dimensions ${ }^{2}$ of semiosis, which made his theory so famous, Morris describes dyadic relations between the three correlates: 1) the formal relation of signs to other signs (syntactic dimension); 2) relation of signs to objects that is to what they denote (semantic dimension); 3) the relation of signs to interpreters (pragmatic dimension) [6, p. 6]. These dimensions may be viewed with certain reservation. Firstly, the first dimension refers to the sign vehicle while the second and the third - to the whole sign. Secondly, the sign vehicle does not provide any information about the object without the interpretant. Thirdly, the third dimension calls for stricter definition of the interpreter which should include the sender and the receiver of signs. Morris does not differentiate between them.

1 Behavioristic here refers to a psychological approach which emphasizes scientific and objective methods of investigation. The approach is only concerned with observable stimulus-response behaviors, and states that all behaviors are learned through interaction with the environment.

2 The term dimension in this context is not used in its primary meaning of a measurable extent of a particular kind, such as length, breadth, depth, or height, but is a synonym of coordinate or parameter. In this paper it is defined as a certain amount of significant parameters, which are crucial for the existence of an object and can provide its comprehensive description. 
To describe functional characteristics of signs from the point of view of semiosis, Morris suggests such terms: syntactics "implicates", semantics "designates" or "denotes" and pragmatics "expresses" [6, p. 7]. By the example of "table' he explains that this sign: 1) implicates (but does not designate) 'furniture with a horizontal top on which things may be placed; 2) designates a certain type of object and denotes objects to which it is applicable and 3) expesses its interpreter. This example testifies to the fact that to describe semantics Morris actually uses terms which characterize the function of the sign vehicle to denote objects and not to provide their interpretation. Semantics does not deal with the relation of signs to objects and considers only the relation of signs to their designata. However, on the same page he writes that semantic rules correlate sign vehicles with their objects providing no explanation of how this correlation occurs.

Results and Discussion. The principal goal of this research is to substantiate the conviction that dimensions of semiosis (defined as the action of sign) should be based primarily on the interpretant which is triadic (Fig. 1). For example, when we approach a fruit stand on the street and see an advertisement for strawberries (primary interpretant) we connect this advertisement with a basket of bright red strawberries on the stand (notional interpretant). If we have in mind to bake a strawberry pie, then the ad signifies for us that we have reached a destination where we may purchase strawberries to bake a pie (cultural interpretant). If we are allergic to strawberries and pass by the same ad and basket of strawberries, we will perhaps quicken our step or reach for an allergy medication.

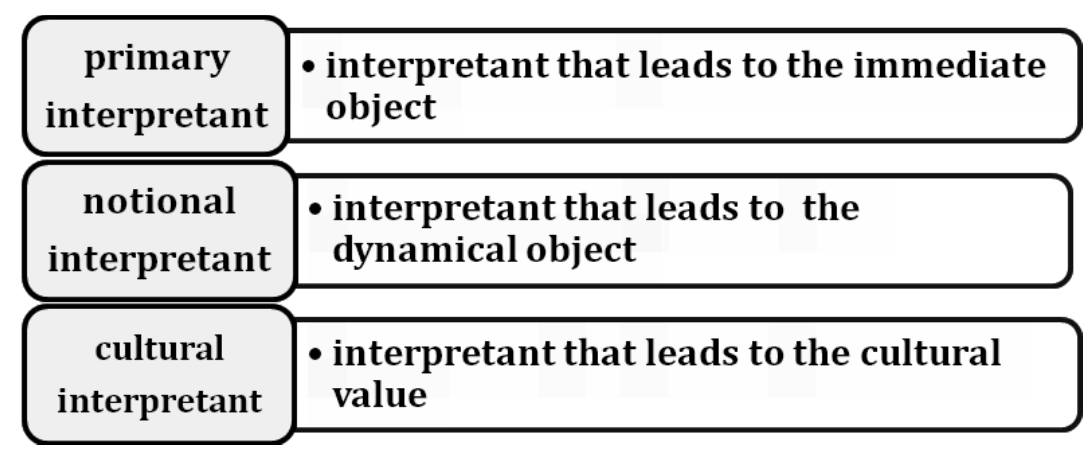

Fig. 1. Triadic nature of interpretant

Proceeding from the suggested triadic nature of the interpretant, I will make an attempt to revise Morris' dimensions of semiosis. First of all, it should be noted that semiosis generates the interpretant. It is the agency of the sign itself rather than the agency of an interpreter. An interpreter's interpretation can be regarded as the perception of the meaning exhibited by the sign itself through the interpretants it generates. Joseph Ransdell argues that meaning creation and change "is never due solely or primarily to what we do: man proposes but the sign disposes" [11]. Thus, the process of semiosis is self-governing: the sign has a power of generating interpretants. However, as it is something that actually occurs or exists (sign vehicle), the dimension of the relation of the interpretant and sign vehicle can be called the 
code dimension of semiosis, since primarily the interpreter perceives the sign vehicle as a unit of code. Semioticians state that all intelligibility depends upon codes, and code in this context is used to designate the set of systemically organized signs and rules of their combining.

Code dimension does not correspond to syntactical dimension as defined by Morris. He views syntactics as "the consideration of signs and sign combinations in so far as they are subject to syntactical rules" [6, p. 14]. His syntactics does not treat qualities of sign vehicles but only their syntactical relations. In the article published by Curt Ducasse in1942, the latter criticizes Morris for the fact that subordination to rules of formation and transformation of signs are crucial for his syntactics and whether the objects formed and transformed are signs beyond those rules is of no importance [3, p. 50]. Code dimension, as suggested in this article, refers to the study of the nature of sign vehicles and codes which they belong to.

The second dimension of semiosis is shaped through the relation of sign vehicle and notional interpretant. The sign vehicle determines notional interpretant and represents designatum. Terms 'determination' and 'representation' are used as advanced by Richard Parmentier who, commenting on Pierce's ideas on the nature of sign, writes that vector of representation is directed from the sign and interpretant to the object and vector of determination - from the object to sign and interpretant, and these are "two opposed yet interlocking vectors involved in semiosis" [9, p. 4]. If these vectors are brought into proper relations, then knowledge of objects through signs is possible.

Notional interpretant provides the connection of identified object with the dynamical object. The suggested definition makes this interpretant close to "concept" as used in modern lingual-and-cultural studies which are directed at the elucidation of the lingual picture of the world. The researchers in the field proceed from the idea that human consciousness is realized in the meanings of lingual units which are formed by the interaction of mental and sensual components [13]. In the semiotic framework, the concept is defined as a synthesizing linguomental entity, as a "unit of thought, which is fixed by a language sign for the purpose of communication" [14, p. 8].

It is claimed in this article that concept is a part of sign and correlates with the notional interpretant for the dynamical object. This makes possible to single out two basic characteristics of the latter: 1) mental nature (is localized in the consciousness and is a mental projection of an object); 2) affiliation to knowledge as a set of relatively stable, objective and collective notional interpretants. Since knowledge is turned into information in the process of transference, it is suggested to call the second dimension of the action of sign the informational dimension of semiosis.

The third dimension of semiosis is associated with cultural interpretant reflecting the evaluative ideas of interpreters. This dimension correlates with Morris' pragmatic rules, but is interpreted in the broader context: the connection of mentality and culture as a "special way of organizing and developing life activities" [15, p. 292] and the relationship with the system of evaluations and values in the mind of the interpreter. Thus, the triadic nature of the interpretant forms the basis for singling out the dimensions of semiosis which are associated with levels and tasks of its analysis (Fig. 2). 


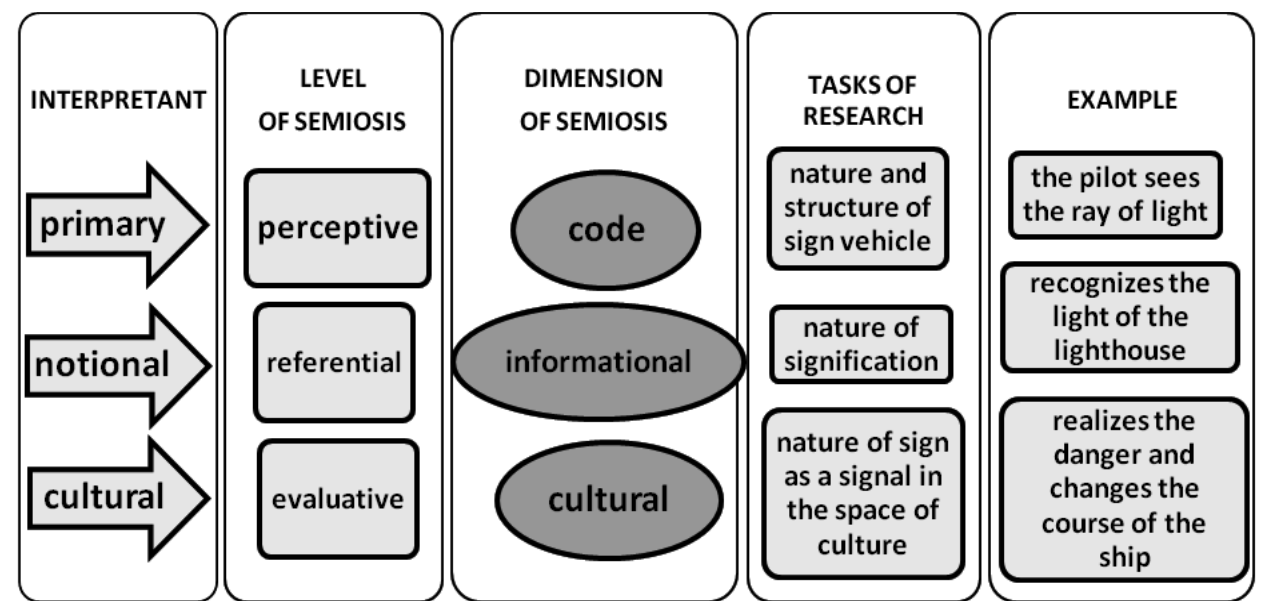

Fig. 2. The potential of interpretant in the field of semiosic studies

Conclusions. Thus, the singling out of code, informational and cultural dimensions of semiosis can modify the ideology of semiotic research as it seeks an explanation of (a) the nature and structure of signs, (b) the nature of signification and (c) the nature of signs as signals in the space of culture - through the notion of interpretant. Understanding the nature of the latter is considered to be crucial for better understanding of semiosis and can become a starting point to develop a theory of semiosis that can illuminate the ensemble of processes that usually fall under the headings of language, culture, and mind.

\section{СПИСОК ВИКОРИСТАНОЇ ЛІТЕРАТУРИ}

1. Allen J. Inference from Signs. Ancient Debates about the Nature of Evidence / James Allen. Oxford: Clarendon Press, 2001. -279 p.

2. Blank D. Philodemus [Electronic resource]. - Mode of access: https://plato.stanford.edu/ entries/philodemus/

3. Ducasse C. J. Some Comments on C. W. Morris's "Foundations on the Theory of Signs" / C. J. Ducasse // Philosophy and Phenomenological Research. - Vol. 3, No. 1 (Sep. 1942). P. 43-52.

4. 'Immediate Object'. Term in M. Bergman \& S. Paavola (Eds.), The Commens Dictionary: Peirce's Terms in His Own Words. New Edition. Retrieved from http://www.commens.org/ dictionary/term/immediate-object.

5. 'Logic'. Term in M. Bergman \& S. Paavola (Eds.), The Commens Dictionary: Peirce's Terms in His Own Words. New Edition. Retrieved from http://www.commens.org/dictionary/term/Logic

6. Morris Ch. Foundations of the Theory of Signs / Charles W. Morris// International Encyclopedia of Unified Science. - Chicago: University of Chicago Press. - Volume 1, Number 2. -1938 . - P. 1-59.

7. Morris Ch. Writings on the General Theory of Signs / Charles William Morris. - The Hague \& Paris: Mouton, 1971. - 486 p. 
8. Nöth W. Representation and Reference According to Pierce/ W. Nöth // International Journal of Signs and Semiotic Systems. - 1(2), July-December, 2011. - P. 28-39.

9. Parmentier R. J. Signs in Society. Studies in Semiotic Anthropology / Richard J. Parmentier. - Bloomington and Indianopolis: Indiana University Press, 1994. - 234 p.

10. Pearson Ch. Theoretical Semiotics and Semiotic Theories [Electronic resource]. - Mod of access: https://www.academia.edu/13674256/Theoretical_Semiotics_and_Semiotic_Theories

11. Ransdell J. Teleology and the Autonomy of the Semiosis Process [Electronic resource]. Mode of access:http://www.iupui.edu/ arisbe/menu/library/aboutcsp/ransdell/AUTONOMY.HTM

12. 'Semiosis'. Term in M. Bergman \& S. Paavola (Eds.), The Commens Dictionary: Peirce's Terms in His Own Words. New Edition. Retrieved from http://www.commens.org/dictionary/term/semiosis

13. Зеленько А. С. Проблеми семасіології в різних лінгвістичних парадигмах / А. С. Зеленько // Лінгвістика. - Луганськ : Луганський національний університет імені Тараса Шевченка, 2010. - № 1 (19). - С. 16-26.

14. Попова 3. Д. Основные черты семантико-когнитивного подхода к языку // 3. Д. Попова, И. А. Стернин // Антология концептов / под. ред. В. И. Карасика, И. А. Стернина. М.: Гнозис, 2007. - С. 7-9.

15. Философский энциклопедический словарь / гл. редакция: Л. Ф. Ильичев [и др.]. Москва : Сов. энциклопедия, 1983. - 840 с.

\section{REFERENCES}

1. Allen J. Inference from Signs. Ancient Debates about the Nature of Evidence / James Allen. Oxford: Clarendon Press, 2001. - 279 p.

2. Blank D. Philodemus [Electronic resource] - Mode of access: https://plato.stanford.edu/ entries/philodemus/

3. Ducasse C. J. Some Comments on C. W. Morris's "Foundations on the Theory of Signs" / C. J. Ducasse // Philosophy and Phenomenological Research. - Vol. 3, No.1 (Sep. 1942). P. $43-52$.

4. 'Immediate Object'. Term in M. Bergman \& S. Paavola (Eds.), The Commens Dictionary: Peirce's Terms in His Own Words. New Edition. Retrieved from http://www.commens.org/ dictionary/term/immediate-object

5. 'Logic'. Term in M. Bergman \& S. Paavola (Eds.), The Commens Dictionary: Peirce's Terms in His Own Words. New Edition. Retrieved from http://www.commens.org/dictionary/term/Logic

6. Morris Ch. Foundations of the Theory of Signs / Charles W. Morris// International Encyclopedia of Unified Science. - Chicago: University of Chicago Press. - Volume 1, Number 2. 1938. - P. 1-59.

7. Morris Ch. Writings on the General Theory of Signs / Charles William Morris. - The Hague \& Paris: Mouton, 1971. - 486 p.

8. Nöth W. Representation and Reference According to Pierce/ W. Nöth // International Journal of Signs and Semiotic Systems. - 1(2), July-December, 2011. - P. 28-39.

9. Parmentier R. J. Signs in Society. Studies in Semiotic Anthropology / Richard J. Parmentier. - Bloomington and Indianopolis: Indiana University Press, 1994. - 234 p.

10. Pearson Ch. Theoretical Semiotics and Semiotic Theories [Electronic resource]. - Mode of access: https://www.academia.edu/13674256/Theoretical_Semiotics_and_Semiotic_ Theories 
11. Ransdell J. Teleology and the Autonomy of the Semiosis Process [Electronic resource]. Mode of access: http://www.iupui.edu/ arisbe/menu/library/aboutcsp/ransdell/AUTONOMY.HTM

12. 'Semiosis'. Term in M. Bergman \& S. Paavola (Eds.), The Commens Dictionary: Peirce's Terms in His Own Words. New Edition. Retrieved from http://www.commens.org/dictionary/term/semiosis

13. Zelenko A. S. Problemy semasiolohii v riznykh linhvistychnykh paradyhmakh / A. S. Zelenko // Linhvistyka. - Luhansk : Luhanskyi natsionalnyi universytet imeni Tarasa Shevchenka, 2010. - №1 (19). - S. 16-26.

14. Popova Z. D. Osnovnye cherty semantyko-kognitivnogo podkhoda $\mathrm{k}$ yazyku // Z. D. Popova, I. A. Sternin // Antologiya kontseptov / pod. red. V. I. Karasyka, I. A. Sternina. - M.: Hnozys, 2007. - S. 7-9.

15. Filosofskyi entsyklopedycheskyi slovar / hl. redaktsiia: L. F. Ilychev [i dr.]. - M.: Sov. entsyklopediia, 1983. - $840 \mathrm{~s}$.

\title{
ВАГОМІСТЬ ІНТЕРПРЕТАНТИ ДЛЯ ОПИСУ PIВНIВ ТА ВИМІРІВ СЕМІОЗИСУ
}

\author{
Надія Андрейчук \\ Львівський національний університет імені Івана Франка, \\ вул. Університетська, 1, Львів, Україна, 79000, \\ nadiyaan@gmail.com
}

Виявлено потенціал ідей Чарльза Морріса стосовно вимірів семіозису для розвитку семіотичних теорій. Проаналізовано, що після Чарльза Пірса всі семіотичні дослідження полягають у вивченні дії знаків, тобто семіозису. 3'ясовано, як Чарльз Морріс тлумачить цю дію і зосереджено увагу на окремих дискусійних положеннях його теорії. Стверджується, що вихідним поняттям для встановлення вимірів семіозису є інтерпретанта, яка є інтегральним компонентом знака і відправною точкою семіотичних міркувань. Обгрунтовано троїсту природу інтерпретанти, яка може бути первинною, поняттєвою та культурною. 3'ясовано, що кожен тип інтерпретанти “працює” на конкретному рівні семіозису: перцептивному, інформаційному та культурному, відповідно. Розгляд співвідношення типів інтерпретанти та рівнів семіозису доповнено з'ясуванням відношень інтерпретанти та об'єкта. Аналіз цих відношень на різних рівнях семіозису дозволив запропонувати три виміри семіозису: кодовий, інформаційний та культурний.

Ключові слова: Ч. Пірс, Ч. Морріс, знак, інтерпретанта, об'єкт, семіозис, рівні семіозису, виміри семіозису. 